\title{
Short Communication \\ Skin sheds as a useful DNA source for lizard conservation
}

\author{
Jose L. Horreo', Maria L. Peláez ${ }^{2}$, and Patrick S. Fitze ${ }^{1,2,3,4}$ \\ ${ }^{1}$ Department of Ecology and Evolution, University of Lausanne, Biophore, 1015 Lausanne, Switzerland. \\ E-mail: horreojose@gmail.com, patrick.fitze@unil.ch. \\ ${ }^{2}$ Department of Biodiversity and Evolutionary Biology, Museo Nacional de Ciencias Naturales (MNCN-CSIC), José \\ Gutiérrez Abascal 2, 28006, Madrid, Spain. E-mail: maaller@yahoo.es. \\ ${ }^{3}$ Instituto Pirenaico de Ecología (IPE-CSIC), Avda. Nuestra Señora de la Victoria 16, 22700 Jaca, Spain. \\ ${ }^{4}$ Fundación Araid, Edificio CEEI Aragón, María de Luna 11, 50018, Zaragoza, Spain.
}

Keywords: DNA extraction, Lacertidae, lizards, moult, sheds, Zootoca vivipara.

Palavras-chave: extração de DNA, Lacertidae, lagartos, mudas de pele, Zootoca vivipara.

It is widely known that the study of the species' genetics is essential for the development of conservation and management strategies. Conservation aims to maintain genetic diversity because it influences the adaptive (Frankel and Soulé 1981) and evolutionary potential of a species (Koljonen et al. 2002). Knowledge about genetic diversity facilitates the identification of management units at the species level (Moritz 1994). This is especially important in small and/ or isolated populations because they are expected to lose genetic variation (Ouborg et al. 2006) and to suffer inbreeding depression (Ellstrand and Elam 1993) over time. However, obtaining

Received 19 February 2015.

Accepted 2 June 2015.

Distributed June 2015. suitable samples may be problematic and should aim at minimizing extinction risks (Reed and Frankham 2003, Kramer and Havens 2009).

A variety of reptile species are only known from small/isolated populations. Obtaining DNA from animals in these populations must be as respectful (non-invasive) as possible in order to avoid problems caused by sampling. Noninvasive DNA sampling would be the safest method, especially from small species. Extracting DNA from faeces is tricky because of fast decomposition. In this sense, one potential noninvasive source of DNA, the shed/moult of the skin, has been successfully employed for DNA extraction in alligators (Yan et al. 2005) and snakes (Bricker et al. 1996, Clark 1998, Fetzner 1999, Dubey et al. 2010). Skin sheds can be collected directly from the individuals, or in the field, since they are usually highly visible. 
Moreover, their decomposition is slower than faeces, which would be an additional advantage.

In this work, skin sheds were obtained from the European common lizard, Zootoca vivipara (Lichtenstein, 1823) (Lacertidae), during population sampling. To date, almost all DNA studies carried out in lizards have sampled a small piece of the tail, toes, or blood. Thus, the DNA source tested here will provide a new, currently unused, method of non-invasive DNA sampling. We extracted and PCR-amplified DNA from ten individuals from three different populations (two in France and one in Spain). Eight of these individuals were adults (three females and five males) and two juveniles (one male and one female). In the field, we carefully collected samples of shed skin (originating from many scales) from the lizard with tweezers and put them into (dry) paper envelops at room temperature. In the laboratory, we employed skin sheds of one to six scales (approximately $1 \mathrm{~mm}^{2}$ per scale) of each individual for DNA extraction using two different methodologies: i) a DNeasy Blood \& Tissue Kit (Qiagen; Verlo, Netherlands), and ii) a Chelex-resine based protocol (Estoup et al. 1996). The former technique was used 4 month and the latter 11 months after collection. DNA quantification (Table 1) showed successful DNA extraction in $100 \%$ of the samples. The commercial kit extracted between 0.4 (ZV9, shed of 5 scales employed) and 3.8 (ZV8, shed of 3 scales) $\mathrm{ng} / \mu \mathrm{l}$ of DNA per sample, and the Chelex method between 24.2 (ZV9, shed of 3 scales) and 48.0 (ZV7, shed of 6 scales) $\mathrm{ng} / \mu \mathrm{l}$ of DNA per sample. Absorbance assay was used to measure the purity of nucleic acids $\left(\mathrm{A}_{260 / 280} \sim 1.8\right.$ means pure DNA). It ranged from 0.70 in ZV6 to 2.60 in ZV10 when extracting with the commercial kit and from 0.56 in ZV7 to 1.05 in ZV4 when extracting with Chelex. DNA from both extraction methods led to good quality DNA and enough quantities to allow for PCR amplification. In all samples, Chelex extraction led to significantly higher DNA quantity than the commercial kit (paired t-test: $t_{9}=12.7, P<0.001$ ), even when employing sheds from a lower number of scales (paired t-test: $t_{9}=-2.3, P=$ 0.047). Moreover, skin shed of one single scale was enough to obtain high DNA quantities when using Chelex. DNA purity was significantly better in the case of the commercial kit (paired t-test: $\left.t_{9}=-3.1, P=0.014\right)$, and in all but one sample (ZV6). In sum, the commercial kit provided much less but purer DNA, than the Chelex methodology. The number of scales from which sheds were employed for DNA extraction (between 1 and 6) was not significantly correlated with the quantity of extracted DNA, neither when using the commercial kit (Pearson correlation coefficient $=-0.584, N=10, P>0.05$ ) nor when using the Chelex protocol (Pearson = $-0.581, N=10, P>0.05)$. The number of scales from which sheds were employed was also not correlated with the purity $\left(\mathrm{A}_{260 / 280}\right.$; Pearson = $0.315, N=10, P>0.05$ for commercial kit; Pearson $=-0.300, N=10, P>0.05$ for Chelex protocol). There was no significant correlation of DNA quantity and purity among methodologies (quantity: Pearson $=-0.150, N=10, P=0.679$; purity: Pearson $=0.049, N=10, P>0.05$ ).

After extraction, two mitochondrial genes were amplified by PCR: NADH dehydrogenase 2 gene (ND2, primers MetF6 and AsnR2; Macey et al. 1997) and 16S ribosomal RNA gene (16S rRNA, primers 984 and 986; Clary and Wolstenholme 1985). PCR reactions containing: 5 Prime Master Mix (5 Prime; Hamburg, Germany) and 1-10 ng DNA in a total volume of $25 \mu \mathrm{L}$. PCR thermal cycling conditions were as follows: initial denaturation at $94^{\circ} \mathrm{C}$ for $5 \mathrm{~min}$ followed by 30 cycles of denaturation at $94^{\circ} \mathrm{C}$ for $30 \mathrm{~s}$, annealing at $50^{\circ} \mathrm{C}\left(16 \mathrm{~S}\right.$ rRNA) or $53^{\circ} \mathrm{C}$ (ND2) for $30 \mathrm{~s}$, and extension at $72^{\circ} \mathrm{C}$ for $90 \mathrm{~s}$, with a final extension step at $72^{\circ} \mathrm{C}$ for $10 \mathrm{~min}$. PCR products were visualized in $1.5 \%$ agarose gels with $10 \mathrm{mg} / \mathrm{ml}$ ethidium bromide. Negative controls were employed to detect contamination and PCR products were purified using Exosap-it for PCR product cleanup (Affymetrix; Santa Clara, CA, USA) before sequencing. Finally, the sequences were visualized and manually edited 


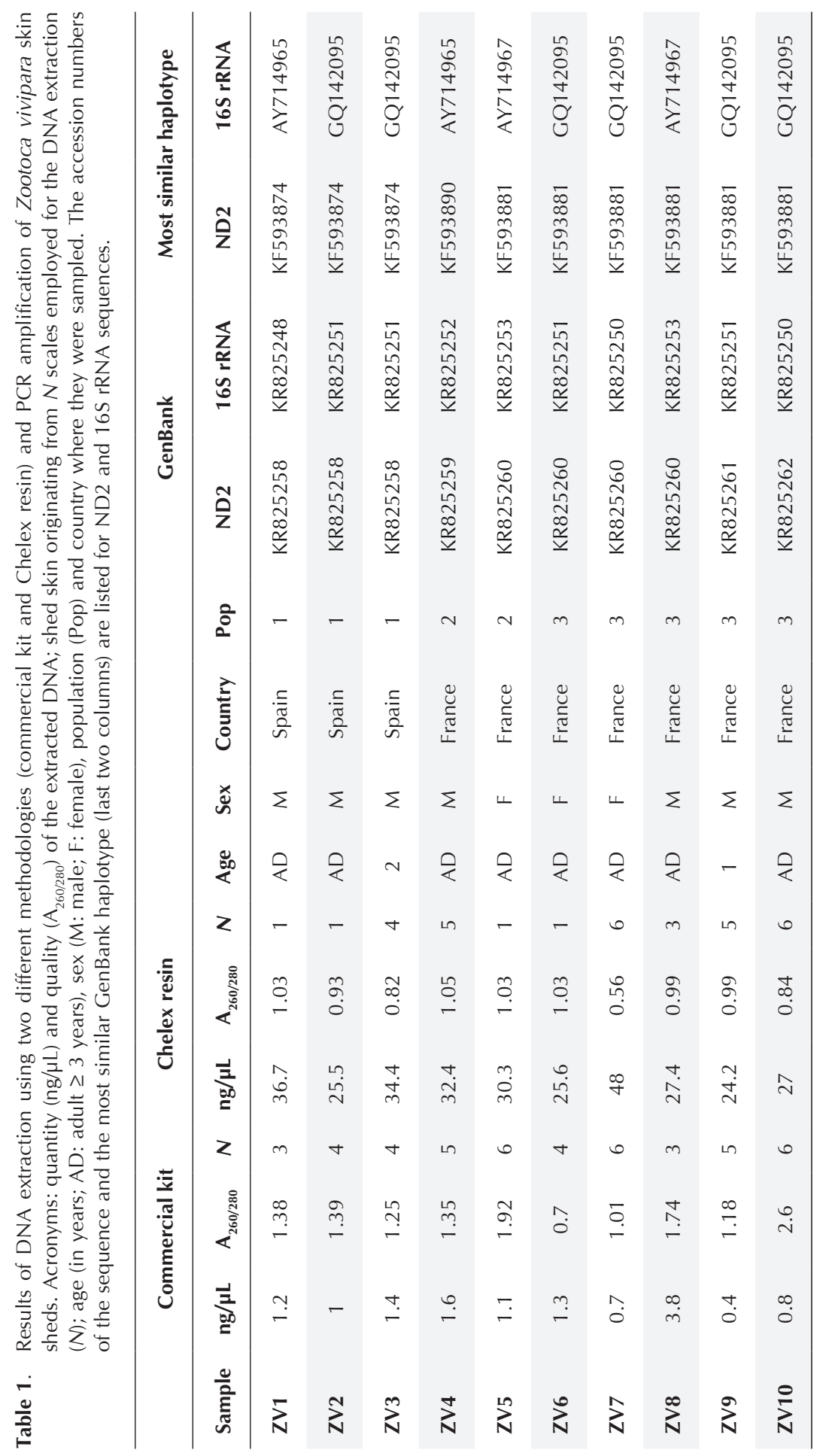


using the BioEdit sequence alignment editor software (Hall 1999).

PCR amplification was assessed using agarose gels and all samples produced bands of the expected length for both mitochondrial genes. Amplification was thus independent of sex, age and origin of the population. Sequencing produced 5 different haplotypes in each of the two partially amplified genes and all sequences were submitted to the GenBank public database (Table 1). BLAST analyses (http://blast.ncbi. nlm.nih.gov) confirmed in all cases that PCR products belonged to $Z$. vivipara and the sequences matched best with three previously known haplotypes (haplotype accession numbers of the most similar GenBank sequences are given in Table 1).

In conclusion, skin sheds of lizards are a useful DNA source, in adults and one-year old individuals and even when only tiny quantities of skin shed are available. This method thus constitutes a new, currently unused, non-invasive method of DNA sampling. This method provided good quality DNA allowing amplifying different mitochondrial genes via PCR. More DNA of lower purity was extracted with the Chelex protocol and less DNA of higher purity was extracted with the commercial kit. Furthermore, skin sheds could be sampled without using alcohol and tubes (reduced equipment costs and reduced weight). The applied methodology is less painful for the animals and requires very little storage space. Sampling of skin sheds thus constitutes an alternative to the frequently employed tail tissue sampling method, which is commonly used in small lacertids.

Acknowledgments. - Project funds were provided by the Swiss National Science Foundation (PPOOP3_128375, PP00P3_152929/1 to P.S.F.) and the Spanish Ministry of Education and Science (CGL2012-32459 to P.S.F.). J.L.H. was supported by a Marie Curie-Clarín CoFund grant (ACA14-26). The study conducted complies with the current Spanish laws and with ASAB/ ABS Guidelines for the Treatment of Animals in
Behavioural Research. The authors declare that they have no conflict of interest. Capture permits were provided by the Préfet de la Region MidiPyrenees, Parc National des Pyrénées, Gobierno de Aragón.

\section{References}

Bricker, J., L. M. Bushar, H. K. Reinert, and L. Gelbert. 1996. Purification of high quality DNA from shed skins. Herpetological Review 27: 133-134.

Clark, A. 1998. Reptile sheds yield high quality DNA. Herpetological Review 29: 17-18.

Clary, D. O. and D. R. Wolstenholme. 1985. The mitochondrial DNA molecule of Drosophila yakuba: nucleotide sequence, gene organization, and genetic code. Journal of Molecular Evolution 22: 252-271.

Dubey, B., P. R. Meganathan, and I. Haque. 2010. Molecular identification of three Indian snake species using simple PCR-RFLP method. Journal of Forensic Sciences 55: 1065-1067.

Ellstrand, N. C. and D. R. Elam. 1993. Population genetic consequences of small population size: implications for plant conservation. Annual Review of Ecology and Systematics 24: 217-242.

Estoup, A., C. R. Largiader, E. Perrot, and D. Chourrout. 1996. Rapid one-tube DNA extraction for reliable PCR detection of fish polymorphic markers and transgenes. Molecular Marine Biology and Biotechnology 5: 295298.

Fetzner, J. W. 1999. Extracting high-quality DNA from shed reptile skins, A simplified method. BioTechniques 26: 1052-1054.

Frankel, O. H. and M. E. Soulé. 1981. Conservation and Evolution. Cambridge, Cambridge University Press. 327 pp.

Hall, T. A. 1999. BioEdit: a user-friendly biological sequence alignment editor and analysis program for Windows 95/98/NT. Nucleic Acids Symposium Series 41: 95-98.

Koljonen, M. -L., J. Tähtinen, M. Säisä, and J. Koskiniemi. 2002. Maintenance of genetic diversity of Atlantic salmon (Salmo salar) by captive breeding programmes and the geographic distribution of microsatellite variation. Aquaculture 212: 69-92.

Kramer, A. T. and K. Havens. 2009. Plant conservation genetics in a changing world. Trends in Plant Science 14: 599-607. 
Macey, J. R., A. Larson, N. B. Ananjeva, Z. Fang, and T. J. Papenfuss. 1997. The novel gene orders and the role of light-strand replication in rearrangement of the vertebrae mitochondrial genome. Molecular Biology and Evolution 14: 91-104.

Moritz, C. 1994. Defining "Evolutionarily significant units", for conservation. Trends in Ecology and Evolution 9: 373-375.

Ouborg, N. J., P. Vergeer, and C. Mix. 2006. The rough edges of conservation genetics paradigm for plants. Journal of Ecology 94: 1233-1248.
Reed, D. H. and R. Frankham. 2003. Correlation between population fitness and genetic diversity. Conservation Biology 17: 230-237.

Yan, P., X. -B., Wu, Y. Shi, C. -M. Gu, R. -P. Wang, and C. -L. Wang. 2005. Identification of Chinese alligators (Alligator sinensis) meat by diagnostic PCR of the mitochondrial cytochrome b gene. Biological Conservation 121: 45-51.

Editor: Jaime Bertoluci 